\title{
MATURATION, SEX RATIO AND FECUNDITY OF THE NILE PERCH LATES NILOTICUS (L.) (PISCES: CENTROPOMIDAE) IN LAKE CHAMO, ETHIOPIA
}

\author{
Elias Dadebo1, Ingemar Ahlgren ${ }^{2}$ and Gunnel Ahlgren² \\ ${ }^{1}$ Department of Applied Biology, Faculty of Natural Sciences, Debub University \\ PO Box 5, Awassa, Ethiopia. E-mail: edadebo@yahoo.com \\ 2 Department of Limnology, Evolutionary Biology Centre, Uppsala University \\ SE- 752 36, Uppsala, Sweden
}

\begin{abstract}
Length-weight relationship, length at first maturity and sex ratio of the Nile perch Lates niloticus (L.) were studied from 342 fish samples collected between February 1995 and May 1996. The relationship between total length (TL) and total weight (TW) for both sexes was curvilinear and statistically significant. The regression equation for the males was $\mathrm{TW}=0.0044 \mathrm{TL}^{3.27}\left(\mathrm{r}^{2}=0.978, \mathrm{P}<0.001\right)$ and that for the females was $\mathrm{TW}=0.0058 \mathrm{TL}^{3.2}\left(\mathrm{r}^{2}=0.991, \mathrm{P}<0.001\right) .50 \%$ maturity size of males and females were found to be $88 \mathrm{~cm}$ and $106 \mathrm{~cm}$ TL respectively. The overall male to female sex ratio of 1: 0.64 was significantly different from the theoretical 1:1 ratio $\left(x^{2}=16.0, P<0.001\right)$. Generally males were more numerous at smaller size classes while females predominate at larger size classes. Forty-nine fish samples that ranged in length from $106.8 \mathrm{~cm}$ to $192 \mathrm{~cm}$ TL and in weight from 17,000 g to 108,000 g TW were used in fecundity estimates. The weight of ripe ovaries ranged from $325 \mathrm{~g}$ to 5,600 $\mathrm{g}$ with the mean weight of $934 \mathrm{~g}$. Fecundity ranged between 1.24 million and 37.44 million eggs. The total and relative mean fecundity of L. niloticus was 6.35 million eggs female ${ }^{-1}$ and 162 eggs g $^{1}{ }^{\mathrm{TW}}$. The average number of eggs $\mathrm{g}^{-1}$ of ovary ranged from 6,200 to 9,300 with the mean number of 8,100 . The relationships between fecundity and $\mathrm{TL}(\mathrm{F}=0.0034 \mathrm{TL} 4.32, \mathrm{n}=49, \mathrm{P}<0.01)$ and fecundity and $\mathrm{TW}$ $\left(\mathrm{F}=0.4357 \mathrm{TW}^{1.55}, \mathrm{n}=49, \mathrm{P}<0.01\right)$ were curvilinear while the relationship between fecundity and ovary weight (OW) ( $\mathrm{F}=8,017 \mathrm{ow}-84,461, \mathrm{n}=49, \mathrm{P}<0.01)$ was linear.
\end{abstract}

\section{Key words/phrases: Fecundity, Lake Chamo, Lates niloticus, maturity, sex ratio}

\section{INTRODUCTION}

L. niloticus is a very fecund fish and one of the few freshwater fishes to spawn pelagic eggs that are shed freely in the water column (Hopson, 1972). Despite this rare trait there have been few studies on the reproductive biology of the species. The fish is known for its sexual dimorphism where the females grow to larger sizes than the males in all areas for which data are available (Hopson, 1972; 1982; Acere, 1985; Ogutu-Ohwayo, 1988; Hughes, 1992). Sexual difference at the length of first maturity has been also documented and considered to be the result of sexual bimaturism (Wiley, 1974), the term used to indicate sexual differences in age at first reproduction (Hopson, 1972; Hughes, 1992). These authors assumed similar growth rates of both sexes (Hughes, 1992) and pointed out the low representation of males at larger sizes to be the result of higher mortality of males at older ages (Hopson, 1972; 1982). But recent study conducted concurrently with this on age and growth of L. niloticus in Lake Chamo (Yosef Tekle-Giorgis, 2002) indicates that females grow faster than males and at sexual maturity both sexes are of comparable age even though their sizes are much different.

Unequal sex ratios in different size classes were well documented where males dominate in smaller size classes and females dominate in larger size classes (Hopson, 1972; Hughes, 1992). Hopson (1972) associates this phenomenon to sexual segregation where the females tend to congregate near the spawning grounds away from the open water. But, Hughes (1992) proposed protandrous sex reversal, with a few fish maturing as primary females. L. niloticus has the smallest egg sizes so far reported for African fish species (Okedi, 1970; Ogutu-Ohwayo, 1988). After hatching the larvae (1.2-19 $\mathrm{mm} \mathrm{TL})$ are pelagic and feed on zooplankton until they move to the littoral regions and start feeding on insect larvae and fish fry (Hopson, 1972). 
Some studies have been conducted on the reproductive biology of other fish species in Lake Chamo, such as Bagrus docmak (Forskål) (Hailu Anja, 1996), O. niloticus (Yirgaw Teferi et al., 2001) and Labeo horie (Heckel) (Elias Dadebo et al., 2003). But the reproductive biology of L. niloticus in Lake Chamo is unknown. The purpose of this study was therefore, to elucidate some aspects of reproductive biology, such as sex ratio, size at first maturity and fecundity of L. niloticus in Lake Chamo, where the species is indigenous and considered to be one of the most commercially important fishes. Since there is no previous study available on reproductive biology of this fish in Lake Chamo, the present study could provide the basic information needed for future management of the species.

\section{MATERIALS AND METHODS}

\section{Study site}

Lake Chamo $\left(5^{\circ} 42^{\prime}-5^{\circ} 58^{\prime} \mathrm{N}\right.$ : Latitude and $37^{\circ} 27^{\prime}-$ $37^{\circ} 38^{\prime}$ E: Longitude) is the most southern of the Ethiopian Rift Valley lakes, with an area of $551 \mathrm{~km}^{2}$ and a maximum depth of $16 \mathrm{~m}$. It is located at an altitude of $1108 \mathrm{~m}$ and about $515 \mathrm{~km}$ south of the capital city Addis Ababa (Fig. 1c). The fish fauna of Lake Chamo, and also that of Lake Abaya, consists of Soudanian species (Beadle, 1981). The fish species are more diverse than those of the other Rift Valley lakes of the country, possibly due to the free passage of the Soudanian species from the Nile system via the interconnections of Lakes Turkana and Chew Bahir (Beadle, 1981).

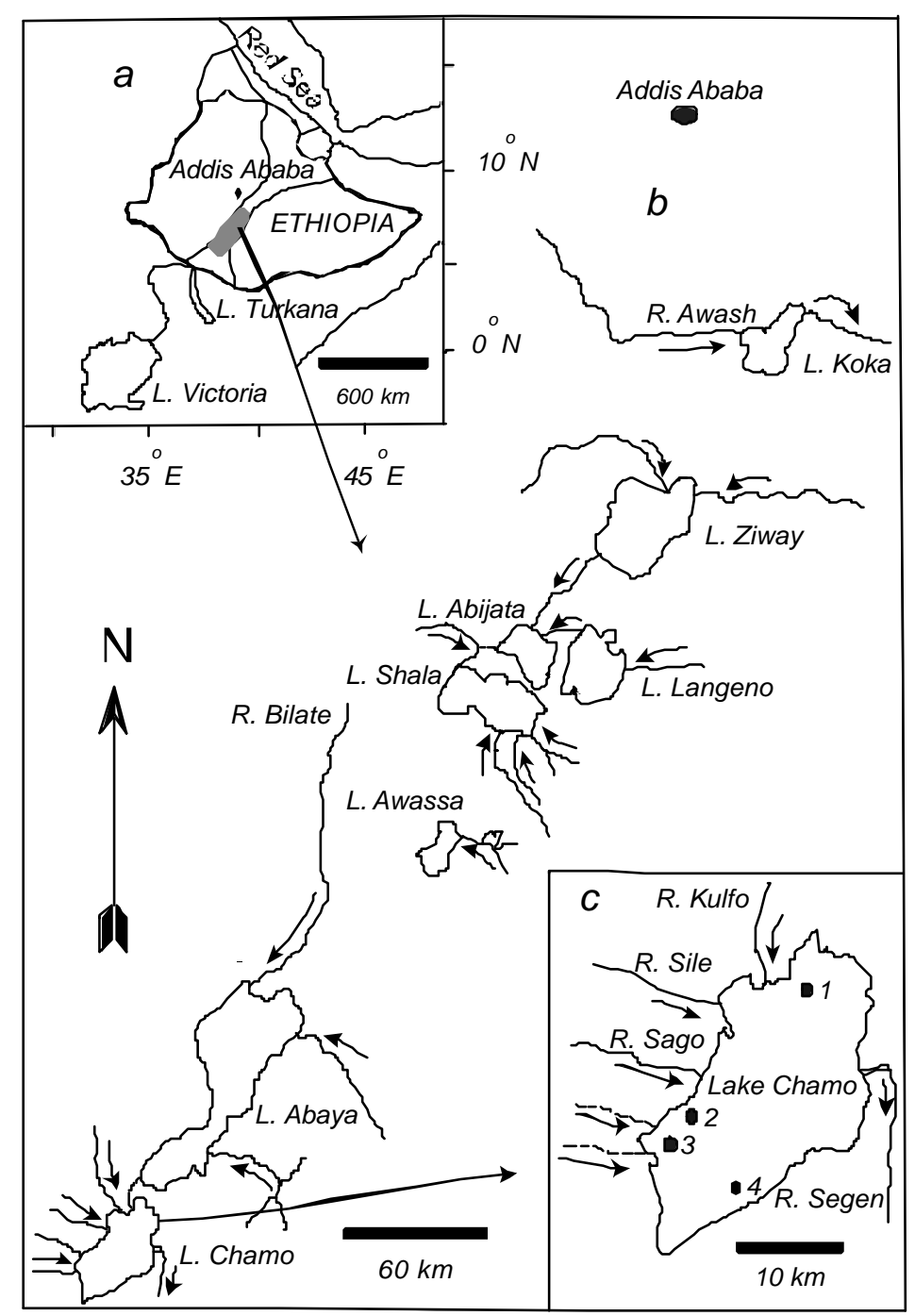

Fig. 1. Map of eastern Africa with the relative location of the Ethiopian Rift Valley lakes highlighted (a), the Ethiopia Rift Valley lakes and their drainage pattern (b) and Lake Chamo with the sampling stations indicated (c) (1- Deset, 2 Bedena, 3- Bole, 4-Suga). 
The main effluents of the lake are Kulfo River that enter in at the north end of the lake, and Rivers Sile and Sago from the west (Fig. 1c). Lake Chamo is connected to Segen River by a broad channel, a river that rises from the northeastern corner of the lake. The morphometric, physical and chemical characteristics of Lake Chamo are given in Elizabeth Kebede (1996). Like many other African freshwater lakes, the dominant cation is sodium and the dominant anions are bicarbonate and carbonate (Elizabeth Kebede et al., 1994). The surrounding region receives two rainy seasons per year, March - May (long rains) and SeptemberOctober (short rains). The mean annual rainfall of the area is about $1,000 \mathrm{~mm}$ (Daniel Gamachu, 1977).

Diatoms and blue-greens dominate the phytoplankton community of the lake (Elizabeth Kebede, 1996). Dominant zooplankton groups include Thermocyclops, Mesocyclops and Moina (Seyoum Mengistou, personal communication). There are more than 20 fish species in Lake Chamo and the inflowing rivers (Getachew Teferra, 1993). The commercially important species are Oreochromis niloticus (L.), L. horie (Heckel), B. docmak (Forskål) and Clarias gariepinus (Burchell). Capture of L. niloticus has been banned as a result of sharp decline of the stock due to over-fishing.

\section{Sampling}

Samples of L. niloticus were obtained from the commercial landings between February 1995 and May 1996. The commercial gill nets used for $L$. niloticus fishery are polyfilament nets of $28,32,36$, 40 and $44 \mathrm{~cm}$ stretched mesh size. Fishermen usually set their gill nets late in the afternoon and lift them the following morning. Smaller specimens were obtained from commercial gill nets that were set to capture O. niloticus and L. horie (14-18 cm stretched mesh size). Total length and total weight of fish were taken immediately after capture using a measuring board and Salter Model $2356 \mathrm{~S}$ balance respectively. All fish were measured to the nearest centimetre. Fish under $1,000 \mathrm{~g}$ were weighed to the nearest $5 \mathrm{~g}$, fish between 1,000 and 5,000 $\mathrm{g}$ were weighed to the nearest $25 \mathrm{~g}$, and fish over 5,000 g were weighed to the nearest $100 \mathrm{~g}$. After dissection the sex and maturity stage of each fish were determined following Holden and Raitt (1974) by categorizing fish as immature (I), recovering spent or developing virgin (II), ripening (III), ripe (IV) and spent (V). Ripe ovaries were removed and weighed to the nearest $1 \mathrm{~g}$ and preserved in $4 \%$ formalin solution.

\section{Length-weight relationship}

We calculated the length-weight relationship using the following formula:

$$
\mathrm{TW}=\mathrm{aTL} \mathrm{L}^{\mathrm{b}}
$$

where

TW is total weight in $\mathrm{g}$, $\mathrm{TL}$ is total length in $\mathrm{cm}$, and

$a$ and $b$ are intercept and slope of the lengthweight regression equation, respectively.

\section{Length at first maturity}

The percentages of male and female L. niloticus, having gonad stages three, four and five in different length groups, were plotted against length for each sex. The size at which $50 \%$ of the fish were mature $\left(\mathrm{L}_{\mathrm{m} 50}\right)$ was determined from the relationship between the percentages of mature fish (P) of length class (L), and coefficients (V1 and V2) as described by the logistic function below (Echeverria, 1987):

$$
\mathrm{P}=\mathrm{e}^{(\mathrm{V} 1+\mathrm{V} 2)} /\left(1+\mathrm{e}^{\mathrm{V} 1+\mathrm{V} 2 \mathrm{~L}}\right)
$$

and the value of $\operatorname{In}_{50}$ can be estimated from the expression:

$$
\mathrm{L}_{\mathrm{m} 50}=-\mathrm{V}_{1} / \mathrm{V}_{2}
$$

Fish collected during the spawning season (i.e., March-June 1995) were used to estimate $\mathrm{L}_{\mathrm{m} 50 \text {. The }}$ proportion of mature fish for each $5 \mathrm{~cm}$ length class was calculated for both males and females and $V_{1}$ and $V_{2}$ were estimated using Marquardt's (1963) algorithm for non-linear least squares regression.

\section{Sex ratio}

A chi-square test was used to determine if the sex ratios varied between different size classes (Sokal and Rohlf, 1995). 


\section{Fecundity}

We estimated total fecundity by weighing all the eggs in the ovaries and counting three sub-samples of $0.25 \mathrm{~g}$ of eggs from various parts of the ovaries. The average number of eggs $\mathrm{g}^{1}$ of preserved wet weight of the ovary was calculated, and multiplied by the total weight of each ovary giving the total number of eggs ovary ${ }^{-1}$ (Snyder, 1983). The relative fecundity was calculated by dividing the number of eggs fish ${ }^{-1}$ by its body weight. The relationship between fecundity (F) and some morphometric measurements such as total length in $\mathrm{cm}$ (TL), total weight in $\mathrm{g}$ (TW) and ovary weight in $\mathrm{g}$ (OW) were determined. The relationship between $\mathrm{F}$ and $\mathrm{TL}$ and between $\mathrm{F}$ and TW were of the form:

$\mathrm{F}=\mathrm{a} \mathrm{X}^{\mathrm{b}}$

where

$a$ is the proportionality constant and $b$ is the exponent.

\section{RESULTS AND DISCUSSION}

\section{Length-weight relationship}

Length-weight relationship of L. niloticus in Lake Chamo was curvilinear and statistically significant $\left(r^{2}=0.98, P<0.001\right)$ (Fig. 2). The regression equation for the males $(n=208)$ was TW $=0.0044 \mathrm{TL}^{3.27}, \mathrm{r}^{2}=0.978$ and that for the females $(n=142)$ was $\mathrm{TW}=0.0058 \mathrm{TL}^{3.2}, \mathrm{r}^{2}=0.991$.

The length-weight regression coefficients for males $(b=3.27)$ and females $(b=3.2)$ indicate considerable allometric growth pattern. Males were heavier and also much older than females of the same length. Length-weight regression coefficients in Lake Chad $(b=3.00)$, Lake Victoria $(b=3.01)$ and Lake Turkana $(b=3.13)$ were close to the cube indicating isometric growth pattern (Gee, 1969; Hopson, 1972; 1982). On the other hand Hughes (1992) reported allometric growth pattern for L. niloticus in Lake Victoria $(b=3.44)$. It is evident that high quality and quantity of food has a direct effect on the condition of fish and thus increases the length-weight regression coefficient (Getachew Teferra, 1993; Zenebe Tadesse et al., 1998).

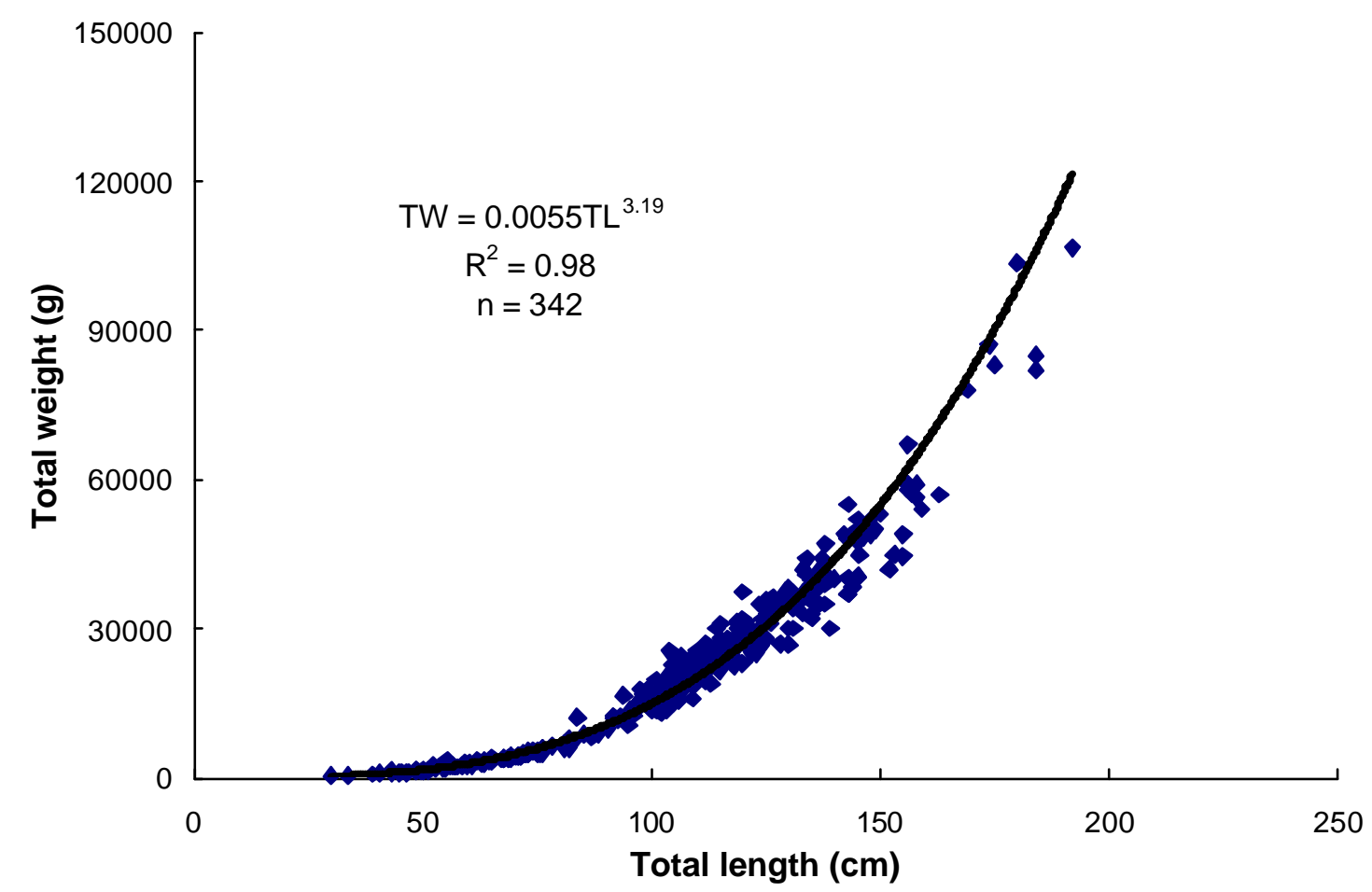

Fig. 2. Length-weight relationship of $L$. niloticus in Lake Chamo. 


\section{Length at first maturity}

The length at first maturity $\left(\mathrm{L}_{\mathrm{m} 50}\right)$ of both male and female L. niloticus (Fig. 3) were estimated to be about $88 \mathrm{~cm}$ and $106 \mathrm{~cm}$, respectively. The results indicate that males mature at a smaller size than the females. The smallest male found with ripe gonads was $81.8 \mathrm{~cm}$ and weighed $7,800 \mathrm{~g}$ while the smallest female with ripe gonads was $98.5 \mathrm{~cm}$ and weighed 15,600 g.

Sexual growth dimorphism exists in L. niloticus where females grow faster than the males (Yosef Tekle-Giorgis, 2002). As a result adult female $L$. niloticus are larger than conspecific males of the same age in the population. In the present study differences at the size of first maturity was large between males and females (Fig. 3). Due to this fact the management practice used in Lake Chamo should consider the $\mathrm{L}_{\mathrm{m} 50}$ of both sexes in order to decide the minimum size of fish allowed in $L$. niloticus fishery. Previous studies have also indicated differences in growth rates between sexes (Hopson, 1972; 1982; Acere, 1985; Hughes, 1992) and pointed out sexual differences in size at first reproduction (Wiley, 1974), where males start reproduction at an earlier age than females (Hopson, 1972; Hughes, 1986). However, recent studies on the age and growth of L. niloticus, using otoliths macrostructure analysis, revealed that both sexes start reproduction at similar a ges but females attain larger size than the males (Yosef TekleGiorgis, 2002).

\section{Sex ratio}

From the total number of 342 fish sampled 208 $(60.8 \%)$ were males while 134 (38.2\%) were females. Except the size class $50-69.9 \mathrm{~cm} \mathrm{TL}$, there was no significant variation in sex ratios of smaller fish $<90 \mathrm{~cm}$ TL (Table 1). Males were more numerous in fish between $90 \mathrm{~cm}$ and $130 \mathrm{~cm}$ TL. More females were caught in larger fish $>130 \mathrm{~cm}$ TL (Table 1). The size of males caught ranged from $33.6 \mathrm{~cm}$ to $163 \mathrm{~cm}$ TL and weighed between $460 \mathrm{~g}$ and 59,000 g. The size of females caught ranged from $30 \mathrm{~cm}$ to $192 \mathrm{~cm}$ TL and weighed between 350 $\mathrm{g}$ and 108,000 g. Generally females are larger than males. The largest female weighed nearly twice the weight of the largest male.

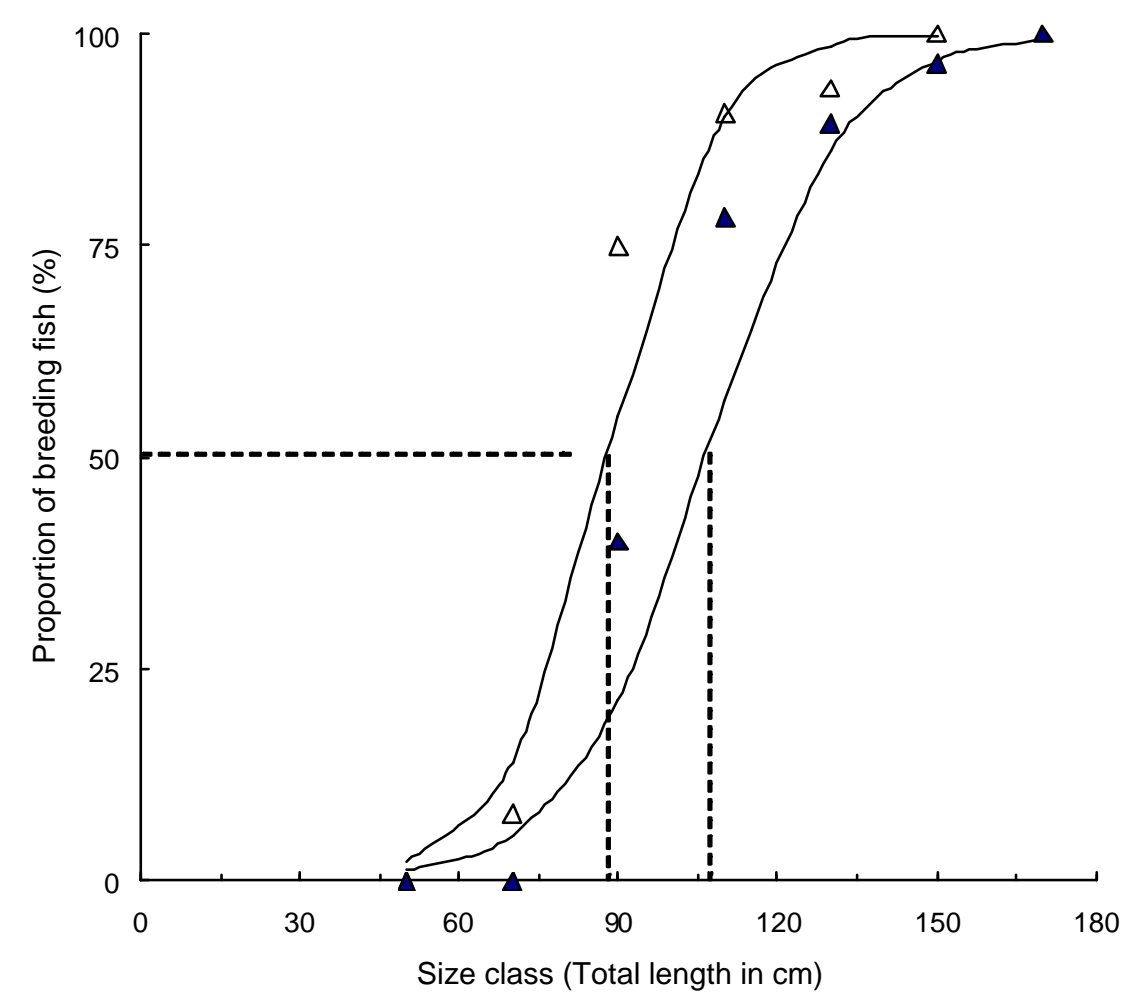

Fig. 3. Length at first maturity of L. niloticus obtained by determining the average length at which $50 \%$ of the fish of both sexes reach maturity (? - males, ? - females). 
Table 1. Number of males and females and the corresponding sex ratios in samples of L. niloticus in Lake Chamo. Samples were grouped in $20-\mathrm{cm}$ size classes.

\begin{tabular}{lllll}
\hline Length $(\mathrm{cm})$ & Males & Females & $\begin{array}{l}\text { Sex-ratio } \\
\text { (male: female) }\end{array}$ & Chi-square \\
\hline $30.0-49.9$ & 6 & 8 & $1: 1.33$ & 0.25 \\
$50.0-69.9$ & 28 & 17 & $1: 0.61$ & $5.38^{*}$ \\
$70.0-89.9$ & 15 & 18 & $1: 1.2$ & 0.27 \\
$90.0-109.9$ & 84 & 5 & $1: 0.06$ & $70.0^{* * *}$ \\
$110.0-129.9$ & 61 & 30 & $1: 0.49$ & $10.56^{* *}$ \\
$130.0-149.9$ & 11 & 39 & $1: 3.55$ & $15.68^{* *}$ \\
$150.0-169.9$ & 3 & 11 & $1: 3.67$ & $4.57^{*}$ \\
$170.0-189.9$ & - & 5 & - & - \\
$>190.0$ & - & 1 & - & - \\
\hline Total & 208 & 134 & $1: 0.64$ & $16.01^{* *}$ \\
\hline
\end{tabular}

*- significant, $(\mathrm{P}<0.05)$, **- highly significant, $(\mathrm{P}<0.01)$, ***- very highly significant, $(\mathrm{P}<0.001)$.

The overall sex ratio of $L$. niloticus in Lake Chamo was significantly different from the theoretical $1: 1$ value $\left(x^{2}=16.0, \mathrm{P}<0.001\right)$. A preponderance of males over females was evident at size classes between 90 and $130 \mathrm{~cm}$ whereas more females were caught in larger fish over 130 $\mathrm{cm}$ TL. Variations in sex ratios have been attributed to segregation of the sexes at different habitats (Hopson, 1972; 1982). Although sexual segregation was not observed in L. niloticus during the present study, this phenomenon was observed in the tiger fish (Hydrocynus forskahlii Cuvier), another piscivorous fish, in Lake Chamo. From March to June 1995 more females were caught (male: female; 1:45) in shallow areas of the lake whereas males predominantly made up the catch early August with a sex ratio of 1:10 (female: male) was recorded (Elias Dadebo, 2002).

A tendency of one sex preceding the other in moving to breeding grounds has been well documented in other fish species (Morgan and Gerlach, 1950; Lowe McConnell, 1958). Mansueti (1961) reported that the white perch Morone americanus (Gmel.) preceded females to the spawning grounds in the Patuxent River, Maryland. As a result during the early migration to the breeding grounds males outnumbered females, but sampling in the estuary downstream almost simultaneously revealed that females were more abundant than the males. Hughes (1986) associates low number of females at lower size classes in Lake Victoria possibly due to protan- drous hermaphroditism. This has to be, however, supported by direct evidence where developmental stages of oocytes are found within testicular tissues (Nolan et al., 2001). Population structure alone can not indicate sex change, because many other biological mechanisms such as differential growth or maturity rates, differential mortality rates, or differential migratory patterns between males and females may cause unequal sex ratios at different size classes (Sandovy and Shapiro, 1987; Matsuyama et al., 1988).

\section{Fecundity}

The weight of ripe ovaries ranged from 325 to $5,600 \mathrm{~g}$ with the mean weight of $934 \mathrm{~g}$. Fecundity varied from 1.24 million eggs to 37.44 million eggs. The total and relative mean fecundity of L. niloticus was 6.35 million eggs female-1 and 162 eggs g $^{-1}$ of body weight respectively. The average number of eggs $\mathrm{g}^{-1}$ of ovary ranged from 6,200 to 9,300 with the mean value of 8,100 eggs $^{-1}$.

The relationship between F and TL (Fig. 4a), F and TW (Fig. 4b) and F and OW (Fig. 4c) were all positive and statistically significant. The best-fit equations to the relationships respectively were:

$$
\begin{aligned}
& \mathrm{F}=0.0034 \mathrm{TL}^{4.322}, \mathrm{r}^{2}=0.779, \mathrm{n}=49, \mathrm{P}<0.01 \ldots \\
& \mathrm{F}=0.4357 \mathrm{TW}^{1.546}, \mathrm{r}^{2}=0.845, \mathrm{n}=49, \mathrm{P}<0.01 . . \\
& \mathrm{F}=8017 \text { ow-84461, } \mathrm{r}^{2}=0.987, \mathrm{n}=49, \mathrm{P}<0.01
\end{aligned}
$$



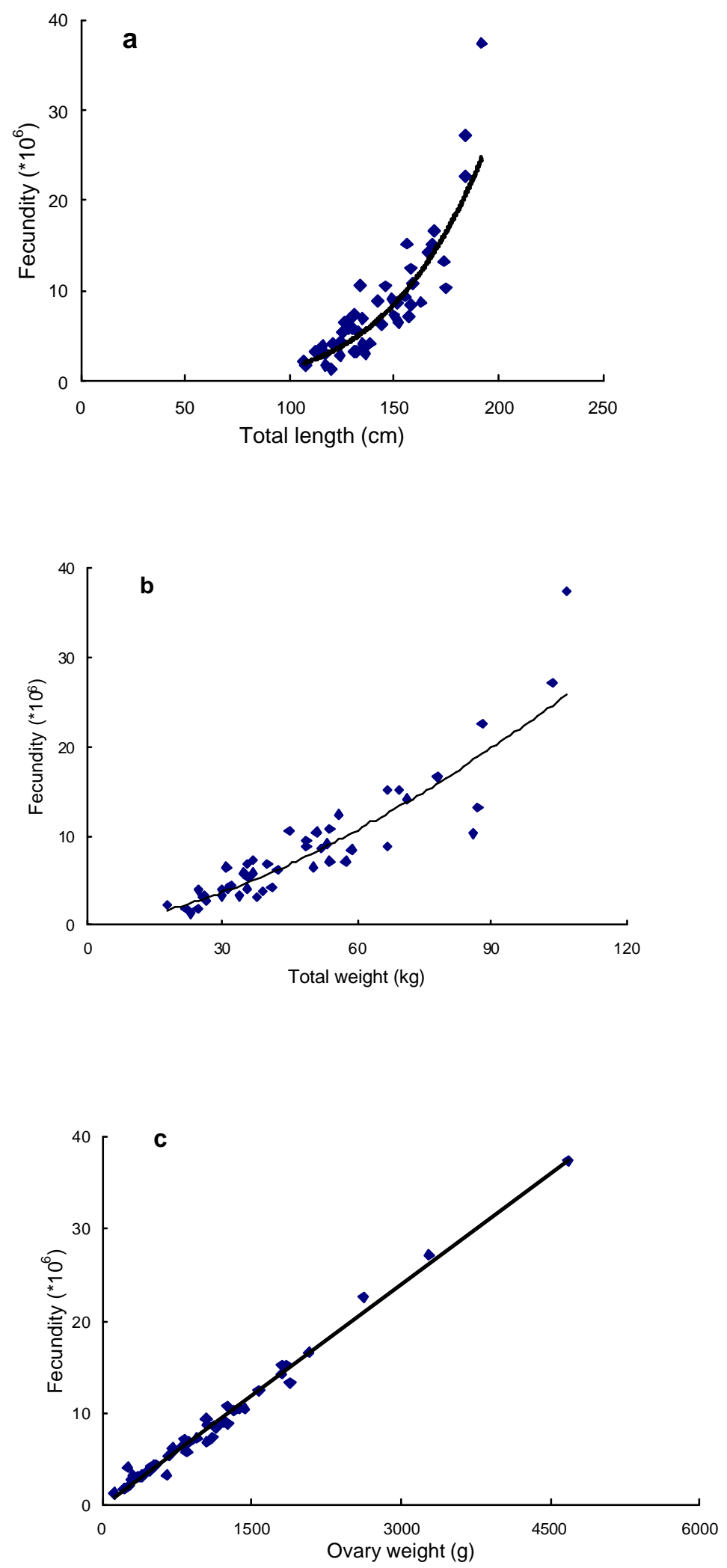

Fig. 4a, b and c. Relationship between fecundity and total length (a), fecundity and total weight (b) and fecundity and ovary weight (c) of L. niloticus in Lake Chamo. 
Fecundity of L. niloticus in Lake Chamo increased in proportion to 4.32 power of length. Wootton (1979) estimated fecundity of 62 different species and reported $b$ values between 1 and 5 , most values ranging between 3.25 and 3.75. Fecundity values estimated in this study were higher for larger fish and lower for smaller ones compared to the values reported by Ogutu-Ohwayo (1988). Since OgutuOhwayo (1988) used standard length (SL) for his estimate, empirical formula relating the two types of measurements ( $\mathrm{TL}=1.12 \mathrm{SL}+4)$ was used for comparative purposes. Taking into consideration the large size at first maturity of Lake Chamo females $(106 \mathrm{~cm})$, it is expected that fecundity will be low at the low end, in comparison with the fecundity of Lake Kyoga females that mature at relatively smaller size $(96 \mathrm{~cm})$ (Table 2$)$. Fish of the same size could be first-time spawners in Lake Chamo, while they could be repeat spawners in Lake Kyoga. First-time spawners normally produce less number of eggs than repeat spawners in fish (Wootton, 1998).

Table 2. Length at first maturity of L. niloticus in different lakes of Africa. The lengths marked with asterisks are the ones that have been converted using the equation $\mathrm{TL}=1.12 \mathrm{SL}+4$.

\begin{tabular}{lccl}
\hline Water body & $\begin{array}{r}\text { Males } \\
(\mathrm{TL}, \mathrm{cm})\end{array}$ & $\begin{array}{r}\text { Females } \\
(\mathrm{TL}, \mathrm{cm})\end{array}$ & \multicolumn{1}{c}{ Reference } \\
\hline Lake Albert & $60^{*}$ & $85^{*}$ & Holden (1963) \\
Lake Chad & 50 & 62.5 & Hopson (1972) \\
Lake Turkana & 65 & 90 & Hopson (1982) \\
Lake Victoria & 54 & 68 & Acere (1985) \\
Lake Kyoga & $50^{*}$ & $96^{*}$ & $\begin{array}{l}\text { Ogutu-Ohwayo } \\
\text { (1988) }\end{array}$ \\
Lake Chamo & 88 & 106 & Present study \\
\hline
\end{tabular}

Differences in fecundity among studies might result from differences in techniques used or factors such as geographical location; temperature and feeding regimes have also been reported (Barbin and McCleave, 1997). Difference in the productivity level of water bodies may also produce variation in size at first maturity and fecundity (Barbin and McCleave, 1997).

The values of exponents when fecundity was related to length and weight of L. niloticus in the present study were comparable to values reported for temperate marine fish species (De Silva, 1973; Wootton, 1979; Gibson and Ezzi, 1980). The total number of eggs (about 37 million eggs) produced female $^{-1}$ was also the highest so far reported for $L$. niloticus. High productivity of the lake $(108 \mu \mathrm{g} n$ Chl $a$, Ahlgren and Ahlgren, personal communication), that result in high density of prey fish, and high temperature of the area could be the main reasons for larger size of L. niloticus and thereby higher total number of eggs produced female ${ }^{-1}$.

In conclusion, length-weight relationships of both sexes of L. niloticus were positively related and statistically significant. The species exhibited sexual growth dimorphism where adult females were much larger than conspecific males of the same age in the population. Because of this sexual growth dimorphism, $\mathrm{L}_{\mathrm{m} 50}$ of females was larger than males. A preponderance of male was evident at smaller size classes whereas the proportion of females was high at larger size classes. Various factors could be responsible for variations in sex ratios at different size classes, such as differential growth or maturity rates, differential mortality rates, or differential migratory patterns between the sexes. The total and relative mean fecundity of L. niloticus in Lake Chamo were among the highest so far reported for the species. High productivity of the water that results in high prey availability, and high temperature of the area could be the main reasons for larger size of the fish and thus higher fecundity.

\section{ACKNOWLEDGMENTS}

We are grateful to the Gamo Gofa Zone Ministry of Agriculture Office and the staff members of fisheries section for participating in sample collection. Dr. Dirk Reyntjens, the then coordinator of LFDP (Lake Fisheries Development Project) is acknowledged for initiating the study and material support. Awassa College of Agriculture (Debub University) and Department of Limnology (Uppsala University) are acknowledged for providing laboratory facilities and the former for providing logistic support for the field trips. The study was financed by MEDAC (Ministry of Economic Development and Cooperation).

\section{REFERENCES}

1. Acere, T.O. (1985). Observations on the biology of the Nile perch (Lates niloticus) and the growth of its fishery in the northern waters of Lake Victoria. FAO Fish. Rep. 335:42-65.

2. Barbin, G.P. and McCleave, J.D. (1997). Fecundity of the American eel Anguilla rostrata at $450 \mathrm{~N}$ in Maine, USA. J. Fish Biol. 51:840-847. 
3. Beadle, L.C. (1981). The Inland Waters of Tropical Africa: An Introduction to Tropical Limnology 2nd ed. Longmans, New York, 406 pp.

4. Daniel Gamachu (1977). Aspects of Climate and Water Budget in Ethiopia. Addis Ababa University Press, Addis Ababa, 71 pp.

5. De Silva, S.S. (1973). Aspects of the reproductive biology of the sprat Sprattus sprattus (L.) in inshore waters of the West Coast of Scotland. J. Fish Biol. 5:689-705.

6. Echeverria, T.W. (1987). Thirty-four species of California rockfishes: maturity and seasonality of reproduction. Fish. Bull. of U.S. 85:229-250.

7. Elias Dadebo (2002). Reproductive biology and feeding habits of some fish species in Lake Chamo, Ethiopia. Unpubl. PhD. Thesis, School of Graduate Studies, Addis Ababa University, 109 pp.

8. Elias Dadebo, Ahlgren, G. and Ahlgren, I. (2003). Aspects of reproductive biology of Labeo horie Heckel (Pisces: Cyprinidae) in Lake Chamo, Ethiopia. Afr. J. Ecol. 41:31-38.

9. Elizabeth Kebede (1996). Phytoplankton in a salinityalkalinity series of lakes in the Ethiopian Rift Valley. Ph. D. thesis, ACTA Universitatis Upsalensis, Uppsala, 43 pp.

10. Elizabeth Kebede, Zinabu Gebre-Mariam and Ahlgren, I. (1994). The Ethiopian Rift Valley lakes: chemical characteristics of a salinity-alkalinity series. Hydrobiologia 288:1-12.

11. Gee, J.M. (1969). A comparison of certain aspects of the biology of Lates niloticus (L.) in some East African lakes. Rev. Zool. Bot. Afr. 80:244-262.

12. Getachew Teferra (1993). The composition of nutritional status of Oreochromis niloticus in Lake Chamo, Ethiopia. J. Fish Biol. 42:865-874.

13. Gibson, R.N. and Ezzi, I.A. (1980). Aspects of the biology of the Spotted Dragnet Callionymus maculates Rafinesque Schmaltz from the West Coast of Scotland. J. Fish Biol. 15:546-553.

14. Hailu Anja (1996). Studies on some aspects of the biology of the catfish Bagrus docmak (Forskål 1775) in Lake Chamo, Ethiopia. MSc Thesis, School of Graduate Studies, Addis Ababa University, $67 \mathrm{pp}$.

15. Holden, M.J. (1963). Report on the Fisheries of Lake Albert. Uganda Fisheries Department, Entebe, 112 pp.

16. Holden, M.J. and Raitt, D.F.S. (1974). Manual of Fisheries Science. Part 2. Methods of resource investigation and their application. FAO Fish. Tech. Pap.115.
17. Hopson, A.J. (1972). A study of the Nile perch (Lates niloticus (L.), Pisces: Centropo midae) in Lake Chad. Overseas Research Publication No. 19, Overseas Development Administration, London, $93 \mathrm{pp}$.

18. Hopson, A.J. (1982). The biology of Lates niloticus (L.) in Lake Turkana. In: A Report on the Findings of the Lake Turkana Project 1972-75, pp. 1285-1299, (Hopson, A.J., ed.) Overseas Development Administration, London.

19. Hughes, N.F. (1986). Changes in the feeding biology of the Nile perch, Lates niloticus (L.) (Pisces: Centropomidae) in Lake Victoria, East Africa, since its introduction in 1960, and its impact on native fish community in the Nyanzan Gulf. J. Fish Biol. 29:541-548.

20. Hughes, N.F. (1992). Growth and reproduction of the Nile perch, Lates niloticus, an introduced predator, Nyanza Gulf, Lake Victoria, East Africa. Environ. Biol. Fish 33:299-305.

21. Lowe McConnell, R.H. (1958). Observation on the biology of Tilapia nilotica L. In East African waters. Reoue Zool. Bot. Afr. 57:129-170.

22. Mansueti, R.J. (1961). Age, growth and movement of the striped bass, Roccus saxatilis, taken in size selective fishing gear in Maryland. Chesapeake Sci. 2:9-36.

23. Marquardt, D.W. (1963). An algorithm for least squares estimation of nonlinear parameters. J. Soc. Indust. Appl. Mathem. 11:431-441.

24. Matsuyama, M., Adachi, S., Nagahama, Y. and Matsuura, S. (1988). Diurnal rhythm of oocyte development and plasma steroid hormone levels in the female red sea bream during the spawning season. Aquaculture 73:357-372.

25. Morgan, A.R. and Gerlach, A.R. (1950). Striped Bass Studies in Coos Bay in 1949 and 1950. Oregon Fish Game Comm. Rep. 14:1-31.

26. Nolan, M., Jobling, S., Brighty, G., Sumpter, J.P. and Tyler, C.R. (2001). A histological description of intersexuality in the roach. J. Fish Biol. 58:160178.

27. Ogutu-Ohwayo, R. (1988). Reproductive potential of the Nile perch, Lates niloticus (L.) and the establishment of the species in Lakes Kyoga and Victoria (East Africa). Hydrobiologia 162:193-200.

28. Okedi, J. (1970). Further observation on the biology of the Nile perch (Lates niloticus L.) in Lake Victoria and Kyoga, EAFFRO Annual Report, pp. 42-55.

29. Sandovy, Y. and Shapiro, D.Y. (1987). Criteria for the diagnosis of hermaphroditism in fishes. Copea 1:136-156.

30. Sokal, R.R. and Rohlf, F.J. (1995). Biometry. The Principles and Practices of Statistics in Biological 
Research. 3rd ed. W.H. Freeman and Company, New York, 859 pp.

31. Snyder, D.E. (1983). Fish eggs and Larvae. In: Fisheries Technique, pp. 165-197, (Nielsen, L.A. and Johnson, D.L., eds). Southern Printing Company Inc. Blacksburg, Virginia.

32. Wiley, R.H. (1974). Evolution of social organization and the life history patterns among grouse. Quart. Rev. Biol. 49:201-227.

33. Wootton, R.J. (1979). Energy costs of egg production and environmental determinants of fecundity in teleost fishes. Symp. Zool. Soc. Lond. 44:133-159.

34. Wootton, R.J. (1998). Ecology of Teleost Fishes. Chapman and Hall, London, 386 pp.

35. Yirgaw Teferi, Demeke Admasu and Seyoum Mengistou (2001). Breeding season, maturation and fecundity of Oreochromis niloticus L. (Pisces: Cichlidae) in Lake Chamo, Ethiopia. SINET: Ethiop. J. Sci. 24(2):255-264.

36. Yosef Tekle-Giorgis (2002). Comparative age and growth assessment of the African catfish, Clarias gariepinus Burchell (Clariidae) and the Nile perch, Lates niloticus (Centropomidae) in the three southern Rift Valley lakes of Ethiopia, Lakes Awassa, Abaya and Chamo. Unpubl. PhD. Thesis, School of Graduate Studies, Addis Ababa University, 160 pp.

34. Zenebe Tadesse, Ahlgren, G. and Boberg, M. (1998). Fatty acid content of some freshwater fish of commercial importance from tropical lakes in the Ethiopian Rift Valley. J. Fish Biol. 53:9871005. 